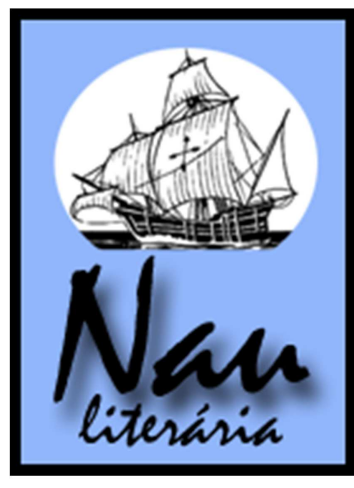

\title{
Imagem, trânsitos e memória em Passageiro do fim do dia, de Rubens Figueiredo
}

\section{Cimara Valim de Melo*}

\begin{abstract}
Resumo: Este artigo propõe-se a analisar o romance Passageiro do fim do dia, de Rubens Figueiredo, nas relações estabelecidas entre as imagens e os trânsitos representados, a memória e o seu reverso - o esquecimento. $\mathrm{O}$ romance brasileiro contemporâneo possui como característica recorrente a exploração do universo memorialístico, capaz de projetar o passado no presente através do tratamento dado ao tempoespaço, que se compõe e se decompõe em fragmentos de imagens pela linguagem. Observar como a memória está inserida no romance em questão e como a narrativa se projeta espaço-temporal e imageticamente é preocupação que move o presente trabalho.
\end{abstract}

Palavras-chave: Romance brasileiro contemporâneo; memória; tempo-espaço.

\begin{abstract}
This paper intends to analyze the novel Passageiro do fim do dia, by Rubens Figueiredo, in its relation to the represented images and transits, memory and its reverse - forgetfulness. The Brazilian contemporary novel has as a recurrent point the investigation of memorialistic world, which is able to reflect the past into the present through its time-space approach, composed and decomposed in fragments and images by language. Observing how memory appears in that novel and how the story projects itself in time, space and images is the principle of this work.
\end{abstract}

Keywords: Contemporary Brazilian novel; memory; time-space.

\author{
[...] ter sabido e ter esquecido o latim \\ é uma possessão, porque o esquecimento \\ é uma das formas de memória, seu impreciso porão, \\ o outro lado secreto da moeda. \\ Jorge Luis Borges (1999)
}

\section{Introdução}

A memória é feita de imagens e símbolos em trânsito constante. Sua composição linguística está atrelada à formação da identidade individual e coletiva, bem como às configurações de tempo e espaço no indivíduo. Isso porque a memória é elemento que une a humanidade ao longo dos séculos e interliga os seres em uma rede linguística infinita. A preocupação dos seres humanos com a memória e o seu reverso, o esquecimento, está

\footnotetext{
* Doutora em Letras pela UFRGS, professora do Instituto Federal de Educação, Ciência e Tecnologia do RS (IFRS). Coordenadora do projeto de pesquisa "Leitura em Rede: gêneros textuais, mídias e incentivo à leitura" (PROBITI/FAPERGS) e editora responsável pela \#Tear: Revista de Educação, Ciência e Tecnologia.
} 
registrada em duas imagens clássicas, a da musa Mnemósine e a do rio Lete. Harald Weinrich (2001, p.13) chama a atenção para essas duas divindades quando analisa a memória em diferentes obras da literatura europeia, pois, se "o homem está naturalmente sujeito à lei do esquecimento, ele é mentalmente um animal obliviscens". Nesse sentido, se a memória perfeita não passa de uma ilusão aos indivíduos, possível apenas para a grande deusa Mnemósine, mãe de todas as musas e filha de Gaia e Urano, sua realidade e seu refúgio residem em seu reverso, no esquecimento. A face obscura da memória é representada por Lete, filha de Éris e responsável pela fonte do esquecimento, o rio Lete, cujas águas promovem aos que as bebem o esquecimento das coisas do mundo (GUIMARÃES, 1999, p.201). A partir dessas imagens clássicas da mitologia, podemos perceber a memória como elemento que acompanha, sob diferentes faces, a história da cultura. Cláudia Rosario destaca a relação entre memória, tempo e linguagem, essencial à compreensão de como aquela é representada pela literatura.

O lugar da Memória é, pois, o lugar da imortalidade. Em Platão, o conhecimento é compreendido como reminiscência: é o amor do belo que desperta na alma as lembranças do conhecimento das ideias perfeitas, obscurecidas pela encarnação. Por sua vez, as formas da atividade amorosa - procriação, poesia, legislação - garantem a "memória das virtudes" que conservamos, e garantem "imortal glória e memória" às obras produzidas e deixadas às gerações, como as obras de Homero e Hesíodo. É a atividade amorosa que gera - filhos ou obras. No caso dos filhos, perpetua-se a memória do sangue, ou, como podemos dizer hoje em dia, dos genes da espécie humana. No caso das obras, permanecem a cultura, os valores, as expressões máximas do pensamento e do sentimento humano coletivos. Em ambos os casos, invisível sob o inexorável transcorrer da duração, sob as inevitáveis transformações seculares, o passado presentifica-se em um gesto, em uma reminiscência ou lembrança que eclode na releitura de um mito, na presença de um objeto que nos evoca um tempo que já não é o nosso mas que contribuiu de modo efetivo para que sejamos o que somos. Em suma, a memória não está apenas no passado trazido à tona pela recordação, mas está presente em nossos corpos, em nosso idioma, no que valorizamos, no que tememos e no que esperamos. A memória nos identifica como indivíduos e como coletividade. A memória permite mesmo que estas linhas sejam escritas em sequência coerente. (ROSARIO, 2002).

Abordada desde a Antiguidade por pensadores como Platão e Hesíodo e pela mitologia greco-romana, presente ao longo da história da literatura e de outras manifestações artísticas, como as artes visuais e o cinema, a memória está ancorada no conflito universal entre fugacidade e permanência. Ao direcionarmos o olhar ao romance brasileiro contemporâneo, observamos que o tratamento dado à memória ocupa lugar de destaque em obras de autores representativos do século XXI, a exemplo de João Gilberto Noll, Milton Hatoum, Chico Buarque, Antônio Torres, Cristóvão Tezza, Luiz Ruffato, Bernardo Carvalho e Rubens Figueiredo, e pode ser observado sob diferentes abordagens estéticas, que nos levam à multiplicidade de estilos e formas do romance contemporâneo. Ao analisar o romance Passageiro do fim do dia (2010), do escritor tradutor carioca Rubens Figueiredo, iremos 
buscar, dessa forma, as relações possíveis entre imagem, memória e trânsitos espaçotemporais, a fim de captar novas possibilidades de tratamento da memória pelo romance brasileiro contemporâneo.

\section{Imagens e trânsitos pelo espaço-tempo da memória}

Em Fedro (2004), de Platão, temos uma das primeiras discussões acerca da memória e de sua relação intrínseca com a linguagem, seja pelo discurso oral ou escrito. Se a vantagem da escrita reside no fato de que esta permite ao indivíduo a ampliação da "possibilidade de armazenagem de informação para além da capacidade mnemônica convencional ao prover os homens de um aparato de registro de fala e do pensamento" (SILVEIRA, 2001, p.144), a da oralidade está na manutenção do recurso interior - e autêntico - de preservação da informação, pois a escrita é produtora de esquecimento. Ao trazer à tona em Fedro a história de Thoth e Tamuz pelas palavras da personagem Sócrates, Platão apresenta, em discurso rico em imagens, a relação íntima estabelecida entre memória, escrita e esquecimento, como podemos observar a seguir:

Dizem que Tamuz fez a Thoth diversas exposições sobre cada arte, condenações ou louvores cuja menção seria por demais extensão. Quando chegaram à escrita, disse Thoth: "Esta arte, caro rei, tornará os egípcios mais sábios e lhes fortalecerá a memória; portanto, com a escrita inventei um grande auxiliar para a memória e a sabedoria". Responde Tamuz: "Grande artista Thoth! Não é a mesma coisa inventar uma arte e julgar da utilidade ou prejuízo que advirá aos que a exercerem. Tu, como pai da escrita, esperas dela com o teu entusiasmo precisamente o contrário do que ela pode fazer. Tal coisa tornará os homens esquecidos, pois deixarão de cultivar a memória; confiando apenas nos livros escritos, só se lembrarão de um assunto exteriormente e por meio de sinais, e não de si mesmos. Logo, tu não inventaste um auxiliar para a memória, mas para a recordação" (PLATÃO, 2004, p.119).

Em Platão, memória e esquecimento são dois universos opostos, que podem ser conectados pela escrita e pela recordação. Se aquela, por um lado, não é um fármaco, pois gera esquecimento, é, por outro lado, elemento gerador de recordação em sua capacidade de despertar na memória o que estava esquecido. Assim, desde a Grécia Antiga, com textos como a Teogonia (1981) ou Fedro (2004), temos a sinalização do caráter ambíguo da escrita, exposto pelos pontos de vistas de Tamuz e Thoth, que nos fazem compreender, na atualidade, as relações, cada vez mais próximas, entre o lembrar e o esquecer, provenientes das imagens clássicas de Mnemósine e Lete. Ao encontro dessa relação intrínseca, estão as palavras de Mario Benedetti em O olvido está lleno de memória (1995) e de Borges em diversas obras, como "Funes, o memorioso", de Ficções e (BORGES, 1998), "O relógio de areia", de $O$ fazedor (BORGES, 1999), e "Um leitor", de Elogio da sombra (BORGES, 1999). A memória 
é feita, pois, de recordações e esquecimentos, os quais fazem parte de vínculos inseparáveis de ausência e presença, de preservação e criação. Conforme Padrós, "se há usos da memória, há também, usos do esquecimento". (PADRÓS, 2002), pois aquela se complementa através deste.

A memória coletiva também sofre processos de esquecimento e consequente reconstrução dos vazios da memória pelo imaginário. Sendo a memória pessoal faculdade tanto da lembrança como do esquecimento, a memória social não se distancia desses pressupostos, pois está sempre sujeita à reconstrução (SOUZA, 2003). Desse modo, a função da imagem é fundamental, já que é ela que oferece a visão acerca do passado e do presente reconstruídos. A memória é feita de imagem, pois, através desta, a memória se torna visível e constrói a identidade individual e coletiva. Lembrar é um ato de preservação da memória e, como ação formada por um processo de seleção, é, ao mesmo tempo, um ato de exclusão de tudo o que não participa dessa seleção.

Traduzir a experiência da imagem não é somente privilégio das artes visuais, em especial da pintura e da fotografia. A literatura exerce uma função imagética importante, pela forma como se apodera do tempo e do espaço em trânsito e como constrói, através deles, representações da experiência cotidiana que atuam como microcosmo da realidade social. No romance brasileiro contemporâneo, as imagens que emanam dos indivíduos e do mundo urbano por meio das narrativas corroboram com a expressão da resistência da obra de arte frente a um mundo marcado pelo apagamento - desmemória - de tudo o que está à margem dos padrões sociais. No romance Passageiro do fim do dia (2010), de Rubens Figueiredo, representação da imagem está presente através de três elementos fundamentais: as recordações da personagem Pedro, que estabelece consigo mesmo um processo de vivificação do passado e, consequentemente proporciona ao leitor múltiplos retratos da vida suburbana brasileira; a visão da personagem frente ao tempo-espaço externo à memória, representado pelo que passa através da janela do ônibus e acontece dentro dele, enquanto os inúmeros passageiros sofrem o fardo de sua condição social; as memórias acerca do olhar de Charles Darwin sobre o Brasil, presentes no livro que acompanha o protagonista ao longo de sua jornada. Em qualquer uma das imagens - do presente vivido e do passado rememorado - vem à tona a visão do "eu" sobre seres anônimos em trânsito constante, que buscam formas de sobrevivência em um país marcado pela desigualdade e pela pobreza. É com a imagem da visão - e da falta dela - que se inicia o romance: um louco aos olhos das pessoas. Um distraído, de certo modo - e até meio sem querer. O que 
também ajudava. Motivo de gozação para uns, de afeição para outros, ali estava uma qualidade que, quase aos trinta anos, ele já podia confundir com o que era - aos olhos das pessoas. Só que não bastava. Por mais distraído que fosse, ainda era preciso buscar distrações. (FIGUEIREDO, 2010, p.7).

A preocupação do 'eu' com relação ao olhar do 'outro' se transforma, ao longo do romance, em motivo para que a própria personagem se torne o observador, a exemplo de Darwin com seus espécimes. Assim, em uma das jornadas de sexta-feira rumo ao encontro com Rosane, sua namorada, Pedro vive com intensidade experiência da memória e da observação de realidades alheias a sua, mesmo ao percorrer com elas o mesmo caminho. Para isso, o distanciamento torna-se elemento chave: "E por esse caminho misturava-se àquela gente, unia-se a alguns e, a partir deles, aproximava-se de todos. Mesmo assim, mesmo próximo, estava bastante claro que não podia ver as pessoas na fila como seres propriamente iguais a ele." (FIGUEIREDO, 2010, p.9). O percurso que passam a fazer juntos, a partir do momento em que tomam o ônibus no sentido do Tirol, é visto por Pedro como semelhante ao processo de evolução, pois alguns indivíduos resistem por mais tempo; outros, fraquejam e ficam para trás (FIGUEIREDO, 2010, p.9).

Pedro não enxerga tudo ao longo do percurso. Na verdade, vive a experiência da observação do 'outro', dentro do tempo-espaço em movimento constante, pelo viés da memória-esquecimento. "O que Pedro na maior parte do tempo não sabia, ou não conseguia lembrar, era que ele mesmo estava ali, junto com os outros. [...] Enxergava bem, mas olhava como que de longe, ou como que através de um furo na parede. Sem ser visto, Pedro não se via." (FIGUEIREDO, 2010, p.11). Assim, aquele que vê os outros e procura analisá-los com detalhamento, sofre a falta de visão sobre si mesmo e é analisado, no romance, pelo narrador onisciente. A visão darwiniana da personagem sobre seus companheiros de ônibus é, portanto, comprometida no momento em que ela se torna uma presa para as artimanhas da narrativa que, à medida que conduz o protagonista à compreensão do mundo a sua volta pelo 'outro', mais o leva ao próprio desconhecimento.

Uma imagem é uma fatia de tempo e de espaço que pode se aglutinar a outras imagens, formando um todo, assim como pode ser desmembrada ad infinitum. Através de imagens da memória, é possível compreender o mundo e (re)configurar a própria identidade, pois elas são capazes de preencher espaços vazios da mente gerados pelo esquecimento ou pela desmemória. Susan Sontag (2004, p.169) afirma que a realidade sempre foi interpretada por meio das informações fornecidas pelas imagens, capazes de "usurpar a realidade" e de, ao mesmo tempo, ser um importante veículo para a sua compreensão. Com relação às expressões do mundo contemporâneo, Sontag (2004, p.171) salienta a preocupação acerca da 
possibilidade de um "mundo-imagem" estar tomando lugar do "mundo real", a ponto de ser perdida a distinção entre cópia e original. Acrescentamos aqui a preocupação com a formação de um mundo-esquecimento a partir da produção e do descarte cada vez mais rápidos das imagens produzidas a todo instante. No romance de Figueiredo, a imagem, em sua relação intrínseca com a memória do protagonista, é elemento essencial para o contato deste com os mundos interior e exterior, com os intertextos e os diferentes tempos circunscritos à narrativa. Em meio a imagens capturadas ao longo dessa travessia, há um conjunto diverso e fragmentário de recordações, selecionadas pela memória pulsante de Pedro, que dirige seu olhar ao passado e ao presente em uma espécie de devaneio:

E pronto: ali estava um bom exemplo do que acontecia tantas vezes com Pedro. Ele sabia disso. De devaneio em devaneio, de desvio em desvio, seus pensamentos se precipitavam para longe, se desgarravam uns dos outros e no fim, em geral, acabavam se pulverizando sem deixar qualquer traço do que tinham sido, do que tinham acumulado. (FIGUEIREDO, 2010, p.11).

Passageiro do fim do dia é um recorte de vida feito através de múltiplas imagens que resistem ao esquecimento e se fazem intermitentemente presentes na memória da personagem. Uma das mais presentes é o espaço do Tirol, visto apenas através do processo de rememoração de Pedro enquanto está no ônibus. Tal espaço, portanto, está suspenso no tempo, como uma imagem fotográfica, e, por isso, promove a mistura entre realidade e imaginação na mente da personagem, que vê esse lugar com estranhamento darwiniano. A suspensão imagética também se dá pelo fato de que o Tỉrol é um espaço do romance sem reais referências geográficas, como uma miragem aos avessos, uma projeção social, um delibáb. Sua imagem é delineada a partir das experiências rememoradas, que se tornam cada vez mais recorrentes à medida que Pedro se aproxima do fim da linha do ônibus. Paradoxalmente, percebemos o Tirol como espaço de desmemória - ou espaço vazio, como quer Zygmunt Bauman - pelo fato de que se torna socialmente inaceitável, o que gera um apagamento coletivo deste e, consequentemente, o esquecimento dos indivíduos anônimos que nele vivem e por ele transitam. Os espaços vazios são lugares destituídos de significado e, por isso, são espaços não vistos. Eles são "lugares que sobram", pois estão vinculados "às sobras dos projetos arquitetônicos e às margens negligenciadas das visões do urbanista", constituindo-se como "resíduos inevitáveis" (BAUMAN, 2001, p.121), explorados pela literatura contemporânea na medida em que esta, como veículo de resistência, busca matéria-prima no descartado e esquecido pela sociedade. O Tirol, como espaço vazio ao qual são direcionados os holofotes pela narrativa de Figueiredo, é o principal símbolo de esquecimento do romance, 
relacionando-se imageticamente com a falta de visão e a obscuridade, as quais estão presentes na análise de Pedro sobre o presente e o passado.

Mas para Pedro, a partir de certo ponto da viagem, a janela só ia servir para cozinhar a resta no sol rasteiro do fim da tarde. E também para bafejar nos seus olhos o gás queimado dos motores em ponto morto, os suspiros curtos da primeira e segunda marchas no trânsito engarrafado. (FIGUEIREDO, 2010, p.21).

Além das imagens proporcionadas por olhares convergentes, há as que provêm da leitura realizada com base na biografia de Darwin, intertexto que corrobora à escolha de uma visão distanciada do 'outro' por parte de Pedro, mesmo quando este traz à tona as lembranças de Rosane. O livro, lido por Pedro enquanto o ônibus executa o seu lento percurso e o enredo vai tomando forma, é, na verdade, uma biografia contendo as memórias de Darwin sobre a expedição que fizera à mesma região em que Pedro se encontra, próximo da Várzea e do Tirol. Em um processo complexo de escritura de narrativas entrelaçadas, as memórias de Pedro se encontram com as de Darwin, mesmo que estejam separadas por cento e setenta anos (FIGUEIREDO, 2010, p.25), e ambas se chocam com a realidade da travessia, do ônibus lotado, do sol escaldante, da sexta-feira interminável, do tráfego congestionado, da rota desviada.

Em meio à leitura, emergem duas importantes imagens, que acompanham o fluxo do romance: Pepsis e Lycosa, respectivamente vespa e aranha, que simbolizam a caçada entre "o tirano e a vítima", o dominador e o dominado, mas também entre a ilusão e a realidade, a memória e o esquecimento. Outrossim, a caçada se dá através da variedade de olhares: o narrador observa Pedro em seus pensamentos e em suas reações; Pedro observa o trabalho ininterrupto e a atenção de Darwin através da leitura; Darwin, seres de um mundo distante ao seu, os quais estão em constante caça pela sobrevivência. Pedro também observa com detalhamento, ao longo da travessia, as pessoas a sua volta e o mundo estranho com o qual passou a conviver desde que conheceu Rosane. Talvez sejam estas as suas grandes presas: Rosane e seu habitat, o Tirol, com suas chagas sociais e relações de dominação. Através do olhar de Pedro, o mundo dobra-se e toma a forma de sua atenção, do mesmo modo que ele mesmo observa nas memórias de Darwin e é analisado pelo narrador. (FIGUEIREDO, 2010, 24). Assim como Pepsis e Lycosa, dominador e dominado assumem posições transitórias, que vão ao encontro do dinamismo das relações sociais no mundo contemporâneo.

As memórias do cientista também destacam a experiência da luz documentada: "a luz daquelas paisagens havia tocado os olhos atentos do sábio inglês" (FIGUEIREDO, 2010, p.65). A imagem da luz é recorrente na narrativa, seja pela sua força em conjunção com o sol 
escaldante, que castiga o indivíduo operário em sua rotina de trabalho e deslocamento dentro dos espaços apertados da urbe, seja pela luz artificial da cidade na noite que se anuncia ao final da sexta-feira. Conforme Chevalier e Gheerbrant (2009), a luz simboliza valores complementares de uma evolução e está associada ao mesmo tempo ao movimento e ao limite entre a vida e as sombras. No caso da luz solar, temos a expressão da força celeste e, paradoxalmente, ao medo e à esperança humanos. Isso porque, assim como é alimento, é também elemento destruidor, que se projeta diariamente no céu como representação da autoridade, do poder e, em seu oposto, da opressão social. As personagens da obra de Figueiredo são castigadas pelo sol poente, castigo, aliás, que representa a rotina de trabalhadores urbanos.

Aquele ir e vir nos fins de semana, aquele movimento de entrar e sair do Tirol, repetido tantas vezes, o simples deslocamento pelas ruas compridas dentro do ônibus com um destino determinado, a oeste, sempre na direção do sol, o sol poente, mas aceso na sua testa quase até o fim - tudo isso bastava para criar e recriar com mais força toda semana um lado de fora e um lado de dentro. (FIGUEIREDO, 2010, p. 148).

A luz também incide por entre as ruas e casas do Tirol, espaço-tempo observado por Pedro em suas memórias. O bairro que outrora era coberto de árvores e sombras, agora é castigado pelo calor do sol, que levanta a poeira das ruas e faz ferver a pobreza local: "No Tirol, agora - e foi Rosane que chamou a atenção de Pedro para isso, um dia -, não havia mais quase nenhuma árvore. O sol atacava direto as ruas poeirentas, onde o capim cinzento só crescia a custo nos cantos dos muros e das pedras." (FIGUEIREDO, 2010, p.31-32). O confronto entre presente e passado no espaço do Tirol se faz presente na mente do protagonista, que recorda o que outrora lhe foi contado por Rosane:

[...] o bairro de Rosane para onde Pedro estava indo dispensava exageros, não disputava primazia nenhuma. [...] Rosane morava no Tirol desde os dois anos de idade, naquela mesma casa. $\mathrm{O}$ aspecto da casa tinha sido melhor na sua infância, como também o aspecto das outras casas, das ruas em volta e de todo o resto, na lembrança de Rosane. O Tirol era um bairro construído inicialmente para alojar militares. As casas originais, de feições semelhantes, tinham todas o mesmo tamanho monótono, mas às vezes elas desembocavam em praças redondas de chão de terra ou se desfaziam em terrenos livres sem nenhum propósito específico. Nessas ilhas, aglomerados de árvores antigas e de copas densas serviam para ventilar um pouco o rigor quadriculado das ruas e dos lotes. (FIGUEIREDO, 2010, p.31-32).

Através do olhar, Pedro projeta para fora de si a própria experiência vivida, relativizando os conceitos de realidade e ilusão. A sucessão de fatos ocorridos enquanto ele percorre o trajeto de ônibus até o Tirol torna-se uma mera projeção da sua realidade interna. Por outro lado, suas memórias são a sua realidade maior, vivas e capazes de fazer emergir pontos esquecidos do passado e do presente daquele tempo-espaço observado. $\mathrm{O}$ 
distanciamento entre o protagonista e sua realidade pode ser observado enquanto este observa as reações do motorista frente à iminência do desvio da rota devido à violência do Tirol:

E Pedro viu pelo espelho retrovisor interno como seus olhos quase brilhavam de tanta atenção embaixo das sobrancelhas muito franzidas e quase juntas, quase trepadas uma na outra, no ponto exato onde começa o nariz. Ao mesmo tempo, Pedro notou que alguns passageiros pegaram os celulares e tentaram fazer contato, em busca de uma solução, de algum caminho. Pediram a ajuda de um parente ou amigo, e logo uns quatro deles disseram que iam descer. (FIGUEIREDO, 2010, p.51).

Inserido nas memórias de Pedro está o tempo-espaço das lembranças de Rosane, cujo ponto de vista aparece na narrativa apenas através do filtro estabelecido pela visão de Pedro. Para Rosane, o Tirol da infância não mais mantinha semelhança com o Tirol atual, transformado pela violência, pelo crescimento desordenado da população, pela pobreza e pelo esquecimento: “As pessoas, nas lembranças de Rosane, pareciam menos pobres do que agora. Contra o fundo de sua memória de criança e de adolescente, aquela transformação, já consumada e sem volta, se apresentava como um processo rápido demais, fácil demais [...] sem resistência, sem alternativa." (FIGUEIREDO, 2010, p.53). Enquanto observador de Rosane, interessa a Pedro o não dito subjacente a ela, o que está por trás de sua condição frágil. Por isso, as imagens formadas com relação a ela estão ora vinculadas a sua condição física, ora a suas aspirações íntimas, ora ao meio onde está inserida. Isso gera em Pedro uma atitude protetora, face à fragilidade daquela gente:

\begin{abstract}
Agora, sentado no ônibus, junto à janela aberta, com o livro aberto de novo nas mãos, Pedro pensava em Rosane. Sob o efeito do que acontecia no ônibus, do que devia estar acontecendo no Tirol e do que falavam à sua volta naquela viagem, Pedro pensou primeiro nas coisas que ela contava sobre seu bairro. Mas logo se distraiu e passou a pensar nos ossos do pulso, nos ossos dos ombros de Rosane. Demorou-se nisso com um certo gosto - já era uma mania que ele tinha, e sabia disso muito bem - tratava-se de uma fixação em algo que, de tanto ele pensar, de tanto ele procurar, tomava a forma e os atributos da última linha de defesa: o osso.

Pedro sentia que era fácil parecer protetor, e até ser de fato um protetor, tamanha a fragilidade aparente em torno de Rosana, tamanha a estreiteza das coisas em que ela podia se apoiar. E isso apesar do seu jeito em geral seguro, apesar da obstinada força de vontade que transpirava de Rosane na maior parte do tempo. (FIGUEIREDO, 2010, p.64).
\end{abstract}

A memória da personagem recupera no tempo-espaço a cidade esquecida, inominada, pela qual circula o protagonista. É pela mente de Pedro que inicia a sua reconstrução, justamente pelos locais mais periféricos, mais distante do centro, onde a personagem inicia seu percurso em busca da cidade perdida. A recuperação dá-se, portanto, através de visões fragmentadas e complementares, que vêm à tona a todo o instante, e são interrompidas por uma sucessão de outras imagens em trânsito constante, formando um fluxo denso de recordações, que se assemelham ao congestionamento das ruas por onde o ônibus em que o protagonista-passageiro está passa rumo ao Tirol. Além de lugares, as imagens também 
evocam gentes esquecidas. Uma delas é João, que Pedro conheceu enquanto esteve no hospital.

Chamava a si mesmo de João, mas não lembrava o sobrenome e às vezes, poucas vezes, quase desconfiava não ser João seu nome verdadeiro. Assim como não lembrava de onde era, onde morava, nem o nome ou as feições de nenhum familiar ou amigo, nem nada anterior a sua chegada ao hospital.( FIGUEIREDO, 2010, p.69).

João contribui à formação de imagens vinculadas ao esquecimento, a um conjunto de seres sem voz, marcados pelo anonimato, pelo desamparo e pela pobreza, no qual estão inclusos Rosane e sua família, bem como os moradores do Tirol. Seres alheios ao próprio mundo, que se tornam presas fáceis à ordem capitalista e às relações de dominação e poder dela derivadas. Seres que vivem também a condição dúbia de Pepsi e Lycosa, pois são ao mesmo tempo caça e predadores em busca da sobrevivência. Em contraste com juízes e médicos, essas personagens vivem a obscuridade do esquecimento; contudo, são iluminadas na mente de Pedro, onde encontram lugar de destaque e são reconhecidas socialmente. $\mathrm{O}$ caráter social da memória, iluminado pelas imagens trazidas por Pedro, é visto por Padrós como fundamentalmente imbricado à identidade, pois carrega consigo a própria história:

Em realidade, há muito tempo que está superada a perspectiva de que a memória é um atributo somente individual. Estudos de diversa origem disciplinar coincidem na experiência compartida da memória, ou seja, na sua natureza social. Mesmo quando envolvem experiências pessoais, as lembranças resultam da interação com outras pessoas (sejam na forma de objetos, palavras, etc.). Não só isso, a memória passa a ser um fator fundamental de identidade e de suporte dos sujeitos coletivos como desempenha, também, uma função importantíssima, tanto na preservação da experiência histórica acumulada, de valores e de tradições, como, em muitas situações, pretende ser a depositária da própria história [...]. (PADRÓS, 2002).

A memória individual está, portanto, interconectada a uma grande rede imagética e espaço-temporal que se chama memória coletiva. Nesse sentido, Bauman diz que "buscamos, construímos e mantemos referências comunais de nossas identidades em movimento - lutando para nos juntarmos em grupos igualmente móveis" (BAUMAN, 2005, p.32), unidos entre si pela memória compartilhada, bem como por relações culturais e espaço-temporais. No romance em análise, assim como ocorre no fenômeno délibáb, a memória de Pedro é uma projeção nítida, clara, de realidades distantes e contempla espelhismos entre passado e presente. $\mathrm{O}$ fenômeno húngaro do délibáb "transporta paisagens muito distantes a horizontes quase desérticos, reproduzindo antes os olhos maravilhados do observador, em dias de calor, o desenvolvimento de cenas distantes" (RAMIL, 2010). Na memória de Pedro, projetam-se múltiplos olhares, que, entrelaçados, formam a representação coletiva de uma dura realidade social - pelo olhar de Pedro, visualizam-se os olhares assustados e, ao mesmo tempo curiosos, do motorista e dos passageiros do ônibus, tendo em vista a iminência da mudança de rota; os 
olhares do juiz, dos meninos descalços, do médico, de Rosane, de João e de tantos outros olhares perdidos entre as diferentes classes sociais; o olhar de Darwin, sempre atento a seus experimentos vivos. Pelos atos de olhar e lembrar, de Pedro, reflete-se a identidade de um mundo esquecido, perdido entre linhas de ônibus e casebres. A importância do ato de lembrar é observada por Padrós na formação da memória coletiva:

Lembrar o passado é um elemento essencial na conformação da identidade, individual ou coletiva. A necessidade de lembrar é, talvez, a principal atribuição da memória. Sem memória não existiriam referências ou experiências. A memória individual que interage com a de outros indivíduos, vincula-se à memória do grupo, formando parte dessa memória coletiva. [...] Lembranças, símbolos e valores identificam o coletivo no espaço e no tempo. São elementos carregados de memória. Memória coletiva. A memória coletiva se concretiza como tal quando as mesmas lembranças, vividas ou transmitidas, voltam de maneira repetitiva, sistemática, com poucas variações, e quando são apresentadas e assumidas como propriedade específica da comunidade. (PADRÓS, 2002).

Assim como as personagens observadas, o esquecido Tirol é um espaço-tempo privilegiado pelo olhar e pelas recordações de Pedro, que o personifica e o projeta na imagem de Rosane: "O Tirol, confundido com Rosane, ou quase tomando o lugar dela, ou mesmo tomando o lugar das pessoas que, como Rosane e sua família, moram lá - o Tirol exercia uma espécie de atração, às vezes violenta, que Pedro queria rechaçar.” (FIGUEIREDO, 2010, p.149). Essa relação de pertencimento vai ao encontro da visão de Le Goff sobre o fenômeno de manipulação da memória coletiva:

Tornarem-se senhores da memória e do esquecimento é uma das grandes preocupações das classes, dos grupos, dos indivíduos que dominaram e dominam as sociedades históricas. Os esquecimentos e os silêncios da história são reveladores desses mecanismos de manipulação da memória coletiva. (LE GOFF, 1996, p. 426).

Pedro resgata justamente o que é esquecido pela sociedade contemporânea. Mesmo vivendo um mundo diferente do encontrado no Tirol, Pedro não fecha os olhos para esse mundo; ao contrário, persegue-o, observa-o palmo a palmo, visualiza-o através de diferentes ângulos em sua memória, em uma relação quase que darwiniana entre observador e observado. Para que essa visão se torne mais nítida, é imprescindível a observação do tempo e do espaço que escorrem, bem como dos trânsitos possíveis entre eles e as imagens provenientes da memória. Padrós (2002) ressalta essa relação móvel entre memória, tempo e espaço: “A memória, tendo relação direta com o passado, manifesta-se, também, a partir das vicissitudes do presente, que ativa aquele passado ou o reconstrói a partir das suas necessidades e indagações."

Memória e esquecimento estão interligados por meio de trânsitos imagéticos ao longo do romance, especialmente à medida que esta se aproxima do fim. Com a imagem do fim do dia, a incidência da luz torna-se menor e os passageiros do ônibus trocam a ansiedade pelo 
sono, pelo esquecimento e pelo cansaço que tomam conta da travessia, como visualizamos a seguir: "Pedro avaliou aquela calma de anestesia que se havia formado entre os passageiros o sono, o meio sono, o esquecimento que atraía, sugava, a repetida promessa de um descanso". (FIGUEIREDO, 2010, p.179). Nesse sentido, a imagem dos passageiros e a imagem do Tirol aproximam memória individual e esquecimento social, pois apresentam, ao mesmo tempo, o que é recordado intimamente pelo indivíduo e descartado pela sociedade. Padrós (2002) destaca que "na disputa pelo que lembrar, é possível pensar em memórias subterrâneas, que surgem e se mantêm nos interstícios dos espaços compreendidos entre o esquecimento e a memória social." Elas expressam as memórias dos esquecidos da memória oficial. A memória de Pedro registra com clareza os não ditos inclusos nas feições dos passageiros, bem como os silêncios contidos em Rosane e em outros moradores do Tirol. Tal registro vai ao encontro das observações de Padrós (2002) sobre os silêncios da memória: “A análise da temática da memória implica em reconhecer que há, como contrapartida, o esquecimento, os silêncios e os não ditos."

Também as imagens dos insetos de Darwin, em especial de Pepsis e Lycosa, fazem-se presentes até o final da narrativa e acompanham a análise que Pedro realiza acerca das gentes do Tirol e, consequentemente, de seu lugar frente àquele tempo-espaço: "Pedro quase lia os pensamentos daquela gente, já eram familiares. Mas, como na fila, no início da viagem, Pedro sentiu também que não era um deles." (FIGUEIREDO, 2010, p.195). Ao mesmo tempo em que Pedro sente que não é um deles, uma sucessão de imagens aproximam o seu trabalho de observador do trabalho de Darwin, descrito no livro que o acompanha ao longo da viagem: "Ele tinha que chegar ao Tirol, à casa de Rosane. Ela já devia estar lá, em volta da mesa da cozinha. Só faltava Pedro. E surgiu na sua memória a imagem de Darwin atravessando o rio, a água lisa, escura, a vara do escravo que tocava o fundo para impelir a balsa”. (FIGUEIREDO, 2010, p.196). Tais relações 'eu’ x 'outro', estabelecidas através da memória de Pedro, são essenciais à compreensão do 'outro' existente em si mesmo, ou seja, às projeções identitárias a ele inerentes; para isso, a imagem do vidro é fundamental para a percepção do processo de alteridade: "Pedro começava a ver a si mesmo no reflexo do vidro: sua imagem surgia mais nítida à medida que escurecia lá fora, assim como as imagens dos outros passageiros. Pedro procurou os olhos deles nos reflexo das janelas". (FIGUEIREDO, 2010, p.197). Essas percepções contribuem à formação de trânsitos entre identidade e alteridade, construídos por imagens da memória, que projeta no indivíduo um mundo esquecido. Nessa busca memorialística pelo 'outro', Pedro constrói relações de pertencimento e dominação, as quais 
possibilitam a ele a própria visualização. Ao descobrir o 'outro' - o Tirol, Rosane, Darwin Pedro descobre a si mesmo.

\section{Considerações Finais}

O romance brasileiro contemporâneo está imerso nas infinitas possibilidades que surgem a partir dos temas memória e esquecimento. Tais constructos definem-se com base nos trânsitos existentes entre tempo-espaço e linguagem, elementos que possuem entre si uma espécie de simbiose, responsável por dar forma à formação imagética da identidade individual e coletiva. A identidade coletiva, em especial, é construída através da experiência compartilhada e da interação, fato que faz da memória repositório da própria história, como observa Padrós:

Em realidade, há muito tempo que está superada a perspectiva de que a memória é um atributo somente individual. Estudos de diversa origem disciplinar coincidem na experiência compartida da memória, ou seja, na sua natureza social. Mesmo quando envolvem experiências pessoais, as lembranças resultam da interação com outras pessoas (sejam na forma de objetos, palavras, etc.). Não só isso, a memória passa a ser um fator fundamental de identidade e de suporte dos sujeitos coletivos como desempenha, também, uma função importantíssima, tanto na preservação da experiência histórica acumulada, de valores e de tradições, como, em muitas situações, pretende ser a depositária da própria história [...]. (PADRÓS, 2002).

Com relação ao romance ao romance Passageiro do fim do dia, de Rubens Figueiredo, as imagens e os trânsitos representados são essenciais à compreensão das noções de identidade e alteridade exploradas ao longo da obra. Conforme Bauman (2005, p.33), a identidade pressupõe movimento, pois acompanha o dinamismo das transformações de um mundo que se move "em alta velocidade e em constante aceleração." Em sintonia com tal dinamismo, estão as visões do 'eu' e do 'outro' provenientes das memórias de Pedro, ao longo de sua jornada de ônibus rumo ao Tirol. Além disso, a outra face da moeda, - o esquecimento - assume destaque quando observamos as lacunas existentes não apenas na mente da personagem, em suas fragmentadas recordações, mas, em especial, na seleção narrativa que esta faz ao trazer à tona imagens de um tempo-espaço perdido, desfigurado pelo que está além do ato de lembrar. Tal processo vai ao encontro das relações existentes entre memória e esquecimento, destacadas por Rosário:

Não nos lembramos de tudo, nem pessoal nem coletivamente. Lembramos aquilo que tem significado, aquilo que é importante. Assim, vivemos entre a memória e o esquecimento, talvez porque vivamos entre o ser e o não ser mais. Certamente precisamos de ambos para viver. A memória nos faz lembrar quem somos e o que nos faz querer ir a algum lugar. (ROSÁRIO, 2002). 
Pedro observa, ao final do romance, o 'eu' esquecido na memória e nos trânsitos alheios. Imagens de pessoas anônimas, que amargam a dura rotina da vida operária em seus trânsitos mesclam-se a imagens de um tempo-espaço esquecido chamado Tirol, com suas ruas empoeiradas e sua gente franzina. Os fragmentos de imagens provenientes da visão de Pedro associam-se, de um lado, ao dinamismo da vida moderna, em suas manifestações individuais e coletivas, e, de outro, ao intertexto a que ele faz referência ao longo de toda a narrativa. Ítalo Calvino observa a visibilidade como um dos valores que precisam ser preservados no novo milênio, possível apenas pela memória humana, através da qual é possível "por em foco visões de olhos fechados", de "pensar por palavras", pois na memória estão depositados "mil estilhaços de imagens" (CALVINO, 1990, p.107-108) à espera de sentido pela junção, em uma mesma matéria verbal, entre "experiência e fantasia" (CALVINO, 1990, p.114). Em busca dessa preservação visual, as memórias da personagem são formadas por imagens provenientes de um certo délibáb - de um espelhismo de memórias sobrepostas, nas quais se incluem as lembranças de Darwin, de Rosane, de Pedro e de tantos outros seres que não podem ser esquecidos, mas que, na realidade, o são. Pela seleção memorialística de Pedro, adentramos um mundo que é conhecido e esquecido ao mesmo tempo. Sobre a seleção entre esse caráter seletivo da memória, Padrós afirma que

\begin{abstract}
A memória é seletiva; não há memória sem esquecimento. Mas não se pode esquecer o que se desconhece. Para que a memória tenha significado para o sujeito, este deve esquecer a maior parte do que viu. É condição básica do fato de lembrar, classificar, combinar e destacar lembranças para exercer, assim, o direito de poder esquecer parte delas. Entretanto, para esquecer devemos conhecer. Se conhecemos, lembramos. Se lembramos, podemos esquecer, podemos exercer o direito da opção de esquecer. (PADRÓS, 2002)
\end{abstract}

Sem os seres anônimos, geralmente excluídos da memória, a roda do mundo não funcionaria. São justamente esses seres que o protagonista do romance de Rubens Figueiredo tem em suas recordações ao longo do trajeto realizado rumo a um espaço também apagado da memória coletiva, o Tirol. Portanto, em movimento entre as luzes da memória e as sombras do esquecimento está o romance Passageiro do fim do dia. Essa obra provoca, pelos trânsitos imagéticos nela gerados através do tempo-espaço, novas possibilidades de percepção do romance memorialístico, pois a memória é ali apresentada justamente pelo que nela falta. Para aproveitarmos a metáfora borgeana, no romance de Figueiredo, a memória assume o que há nela de mais profundo: o outro lado secreto da moeda. 


\section{Referências}

BAUMAN, Zygmunt. Identidade. Rio de Janeiro: Jorge Zahar, 2005.

Modernidade líquida. Rio de Janeiro: Jorge Zahar, 2001.

BENEDETTI, Mario. O olvido está lleno de memoria. Buenos Aires, Sudamericana, 1995.

BORGES, Jorge Luis. Obras completas. São Paulo: Globo, 1998. V.1.

Obras completas. São Paulo: Globo, 1999. V.2.

CALVINO, Ítalo. Seis propostas para o próximo milênio. São Paulo: Companhia das Letras, 1990.

CHEVALIER, Jean; GHEERBRANT, Alain. Dicionário de símbolos. 23.ed. Rio de Janeiro: José Olympio, 2009.

FIGUEIREDO, Rubens. Passageiro do fim do dia. São Paulo: Companhia das Letras, 2010.

GUIMARÃES, Ruth. Dicionário da mitologia grega. São Paulo: Cultrix, 1999.

HESÍODO. Teogonia: a origem dos deuses. São Paulo: Iluminuras, 1981.

LE GOFF, Jacques. História e memória. Campinas: UNICAMP, 1996.

PADRÓS, Enrique Serras. Usos da memória e do esquecimento na História. Literatura e autoritarismo: o esquecimento da violência, n. 4, 2002. Disponível em:

<http://w3.ufsm.br/grpesqla/revista/num4/ass02/pag01.html.> Acesso em: 02 mar.2012.

PLATÃO. Fedro. São Paulo: Martin Claret, 2004.

RAMIL, Vitor. Délibáb. São Paulo: Cooperdisc, 2010. CD-ROM.

ROSARIO, Cláudia Cerqueira. O lugar mítico da memória. Morpheus: Revista Eletrônica em Ciências Humanas, ano 1, n. 1, 2002.

SILVEIRA, Ronie Alexsandro. Memória e escrita no Fedro de Platão. Cadernos de atas da ANPOF, n.1, 2001.

SONTAG, Susan. Sobre fotografia. São Paulo: Companhia das Letras, 2004.

SOUZA, Rogério Ferreira de. Favela e os espaços monumentalizados: um lugar de memória coletiva e símbolo de resistência. Morpheus: Revista Eletrônica em Ciências Humanas, ano 2, n. 03, 2003. Disponível em: http://www.unirio.br/morpheusonline/N\%C3\%BAmero\%2003\%20\%20especial\%20mem\%C3\%B3ria/Rog\%C3\%A9rio\%20Souza.htm >. Acesso em: 02 mar. 2012.

WEINRICH, Harald. Lete: a arte e crítica do esquecimento. Rio de Janeiro: Civilização Brasileira, 2001. 